\title{
The complexity of cultural outcomes as Indonesian language teaching material for foreign speakers (BIPA)
}

\author{
Gustia Haryati, Andayani, Atikah Anindyarini
}

Universitas Sebelas Maret, Surakarta, Indonesia

\begin{abstract}
Culture plays an important role in language learning with the aim of promoting communication skills for foreign students. Language is also a set of spoken voices which are arbitrators and must be meaningful. The main function of language is as a tool and communication tool. As for language learning the role of the instructor is needed because professional instructors in language and culture support literacy, so students want to have literacy and cross-cultural skills. Thus, cross-cultural understanding is also needed to be a supporting component in the language learning process of a country, without knowing the culture in the local area, foreign students will have difficulty in socializing with the local community. In the process of communicating the use of individual languages is always associated with language, language users and language use. This research was written with the aim of describing the cultural results contained in Indonesian textbooks for foreign speakers. This research was written with the aim of describing the cultural results contained in the textbook. The level of the textbook analyzed was my best friend's level a1, A2, B1, and B2. The research method used in conducting research is a qualitative descriptive research method. Based on the results of the study, found several cultural results at each level or level. The results of this study are: livelihood $(\mathrm{MH}) 37.5 \%$, life equipment and technology $(\mathrm{PH}) 6.25 \%$, arts $(\mathrm{K}) 31.25 \%$, knowledge systems $(\mathrm{SP}) 6.25 \%$, religion $(\mathrm{R}) 6.25 \%$ and language $(B) 12.5 \%$.
\end{abstract}

Keywords-Teaching material, the complexity of cultural outcomes, BIPA, Indonesian Friends.

\section{INTRODUCTION}

Learning an important aspect of understanding languages. Language and culture are two interrelated aspects. The Indonesian nation is rich in culture where each region/region has a unique and diverse culture. With the times, the Indonesian language is not only taught by native speakers, but the BIPA program has begun to develop internationally. In communicating with the community, good language acquisition is a supporting factor [1]. The language also has a role to link one idea with another idea, one distance from another distance and one interest with the interests of others. It can be imagined/felt, Indonesian is used as a unifier between regions in Indonesia. The diversity of regional languages in each region requires a means of mediation so that it is accepted by other communities [2].

Studying culture is the same as exploring how cultural meanings are symbolic in language as a sign system. Indonesian as a medium for developing culture, knowledge, and technology[3]. Previous research findings explain that cultural content integration (CCI) is very important in learning languages such as Spanish because of high equity-based trust. And become one of the ways to promote cultural pluralism, cultural pride and to attract students' interests. This is an opportunity for students to make conceptual connections and improve learning [4]. Thus, CCI plays a very important role in the success of student learning. As in previous studies explained that cultural factors can influence student behavior and attitudes. Therefore, culture is the main requirement for planning specific actions to improve student learning success [5].

In addition, understanding cultural elements in society is an important factor in learning the language of a country. For example, foreign students come to Indonesia to learn Indonesian [6]. Thus, foreign students before coming to Indonesia have a basic knowledge of cultural understanding found in Indonesia. Therefore the context of BIPA learning, cultural aspects must be systematically integrated with language learning, so that foreign students / foreign speakers easily learn and appreciate the behavior and values of the prevailing social culture in the local area [7].

Through BIPA learning, it functions as a media to inform Indonesian culture to foreign speakers, because it uses the Indonesian language which means to express the 
cultural values of Indonesian people. Therefore, supporting factors for the success of BIPA learning will not be optimal if they do not include the socio-cultural aspects prevailing in society [8]. The supporting factors that influence the learning outcomes of foreign students, including initial knowledge, prospects, and learning behavior. Previous knowledge is one of the positive energies that build an impression on foreign students so that it encourages foreign students to have learning prospects. The findings from previous studies state that investigating the effects of intrinsic motivation and prior knowledge, students on Chinese learning achievement indicate that previous students' intrinsic knowledge and motivation influence student achievement in learning Chinese [9].

Foreign students studying in Indonesia have different cultural backgrounds and the purpose of learning Indonesian is also different. Therefore, the teaching of foreign students also has a difference with the teaching of native students / native speakers in the local area. Therefore BIPA instructors must look at the first language background (B1) of each student[10].

So that, in BIPA learning teachers should consider concepts, experiences and learning readiness thatis oriented towards student learning. This is needed to regulate the environment, both social and psychological environments, diagnosis of learning needs, careful planning, clear learning goals, and careful planning [11]. As for this study, the levels used as research samples are books "Indonesia Sahabatku" level A1, A2, B1, and B2.

\section{REVIEW OF LITERATURE}

In creating effective programs to build participant language skills and intercultural abilities, program developers strive to implement five principles of intercultural language learning: active construction; making connections; interaction; reflection; And Responsibility [12]. Underlying these principles are sociocultural social constructivist learning theories that place importance on the background and experience of learners, social participation, use of mediation tools (tools and technology) and the position of students in the 'community of practice' [13].

The idea of facilitating participants to form a community of practice (COP) is important to the program. COP is defined as a group of people who learn through active participation in shared social practices around shared goals. For example in music games like Gamelan [14].

The main dimensions of the COP are: 1) mutual involvement-how members interact, contribute and connect; 2) joint ventures - how they negotiate the goals of their union, mutually support and share responsibility; and 3) shared repertoire - how they develop communal resources and shared language, history, and identity or sense of belonging [15].

The social learning that takes place in COPS has five levels that make up the 'value creation' cycle: direct value (direct benefit member experience); potential value (knowledge capital built for potential future use); applied value (how learning is applied in practice in certain situations); realized values (members' perceptions of how successfully students can apply their knowledge capital to their practice); and reframe / transformative values (reframe strategies, goals, and values to meet the new definition of success) [16].

\section{RESULTS AND DISCUSSION}

The results of the study in the Indonesian Sahabatku book on the complexity of cultural outcomes are as follows:The results of the study are in table 1: The Complexity of Cultural Results in the BIPA textbook "Indonesian Sahabatku"

Table 1. Percentage of Complexity of Cultural Results in Textbooks "Indonesian Sahabatku"

\begin{tabular}{llll}
\hline No. & $\begin{array}{l}\text { Komppleksitas } \\
\text { Hasil Budaya }\end{array}$ & Jumlah & Presentasi \\
\hline 1. & Livelihood (MH) & 12 & $37.5 \%$ \\
2. & $\begin{array}{l}\text { Life equipment and } \\
\text { technology (PH) }\end{array}$ & 2 & $6.25 \%$ \\
3. & Art (K) & 10 & $31.25 \%$ \\
4. & Knowledge System & 2 & $6.25 \%$ \\
& (SP & & \\
5. & Religion (R) & 2 & $6.25 \%$ \\
6 & Language (B) & 4 & $12.5 \%$ \\
Total & & 32 & $100 \%$ \\
\hline
\end{tabular}

The results of the above study indicate that there is a complexity of cultural outcomes in the BIPA textbook. The culture taught to foreign students is a culture that is found in Indonesia globally. The complexity of cultural products is divided into 6 parts namely; 1. Language (B); 2. Knowledge System (S.P); 3. Living Equipment \& Technology (PH); 4. Livelihoods (MP); 5. Religion (R) and 6. Art $(\mathrm{K})$. From the six sub-forms of culture the complexity of cultural products, it can be explained about the data related to the complexity of cultural results in the BIPA textbook "My Friends of Indonesia" contained in the description below: 


\section{The Complexity of Cultural Products in the form of Language}

The complexity of cultural outcomes in the form of language shows some of the findings of the data in the textbook "Indonesian Sahabatku". The data findings are in the form of language culture results presented in spoken language. There is some data that is authentic evidence in the textbook "Indonesian Sahabatku". The data found is not dominant and not much related to cultural outcomes in the form of language. The findings are in the form of data. The first data is the existence of the name "Say hello (Tegur Sapa)" in Indonesian society. Reprimand greetings become Indonesian culture that respects fellow human beings. Consider the data quote that represents a number of data contained in the book "Indonesian Sahabatku":

\section{"Say hello (Tegur Sapa)}

Indonesia is rich in regional culture. One community that is thick in culture is the Sundanese people, especially those in the village".

The quote above shows that the habits of Indonesian people when meeting with friends, friends, work relatives, and new people, always greet that person. This shows, that Indonesians are smiling and friendly to everyone. For example, when meeting on the streets, markets and tourist attractions, greet each other when they see people they know and when they meet people they don't know, only their lips smile. As for the other data as follows:

"In Javanese culture, the term Priyayi or blue blood is a social class that refers to the aristocratic class".

From the quote above, showing the name "Priyayi" is a Javanese term for social class in the aristocratic class. For example, the highest class in society as owned by the royal family. Next, the third data as follows:

\section{"Merantau Culture}

The culture of wandering is one of the habits of Indonesian people, especially in the Batak people"

The quote above shows that in Indonesia the term wandering is that Indonesian people go to a place that is not their native land. Where migrants become Indonesian culture that serves to earn a living, knowledge and so forth for the sake of living life or seeking experience.

\section{The Complexity of Cultural Results in the Form of Knowledge Systems}

Cultural products in the form of a knowledge system cannot be separated from objects that become tangible manifestations and authentic evidence of the life and development of a knowledge system in society. The creation of an object that is real and can be seen and even enjoyed and utilized by humans requires something called a knowledge system.

The textbook "Indonesian Sahabatku" in which data shows how the knowledge system is owned and controlled by the community or reflected in the material. The cultural products contained in the textbook "Indonesian Sahabatku" are representations of cultural products. These cultural products are the result of the knowledge system that is owned and the technique of how the objects are created. The form or result of the culture in the form of the complexity of the knowledge system in the textbook "Indonesian Sahabatku" which is in the form of a knowledge system in creating diverse forms of food.

The knowledge system in creating food is described in the textbook "My Friends of Indonesia" through traditional medicine when catching a cold with "scraping". The quotations contained in the textbook "My Friends of Indonesia" as follows:

"Scraping (Kerokan) is the act of bending your back so that the condition of pain or discomfort is reduced"

The quote above shows that in the textbook "Indonesian Sahabatku" introduces how to deal with cold symptoms. The kerokan culture has been famous since the Kingdom of Zama first. This therapy is very popular and popular among the people of Indonesia. The results are effective and the costs incurred are very cheap to cure colds. By using a coin and a coin that serves to attract evil spirits that make sick sufferers out. The redder and darker that means the more severe colds. The other quotations contained in the textbook "Indonesian Sahabatku" are as follows:

"Weaving is the proud cultural heritage of Indonesians"

The above quotation shows that in the textbook "Indonesian Sahabatku" introduces the way of Indonesian culture, namely weaving. Where weaving has been famous since ancient times and is still developing today. Weaving is the result of human crafts made from yarn, wood fiber, cotton, silk and so forth. This weaving is also related to culture, beliefs, environment, and knowledge in Indonesia. Good quality weaving depends on the basic ingredients used.

\section{The Complexity of Cultural Products in the Form of Living Equipment and Technology Systems}

The complexity of cultural products in the form of living equipment and technology systems is also reflected in the textbook "My Friends of Indonesia". Specifically in this study found 2 data that represent the concept. Cultural 
products or objects of human work related to equipment and technology in the book "My Friends of Indonesia" are described through the following description:

The first data finding is the complexity of cultural outcomes in the form of transportation tools. Indonesian people, especially in Java, use tricycles as a mode of transportation. Pedicab is three-wheeled transportation. This object is one form of a product of the work of the community that shows mastery of living equipment systems and technology. The following excerpts found in the textbook "My Friends of Indonesia" as a means of transportation for the people of Indonesia:

"In several cities in Indonesia, means of transportation the tricycle is called a rickshaw.

Becak is pedaled by a driver"

The above quotation shows that in the textbook "My Friends of Indonesia" introduces a classic and nonpolluting means of transportation in Indonesia, "Becak". The pedicab has two versions, the first time in Indonesia there is a wooden pedicab using a bicycle with human or manual propulsion. Whereas the second is a motorized becak or engine rickshaw that uses a motorcycle as a mover. When you go to the cities of Yogyakarta and Surakarta, you can find both types of pedicabs. The other quotations are as follows:

"Introducing cooking and eating plates such as plates, forks, spoons, knives, gas stoves, electric stoves, refrigerators, irons, vacuum cleaners, air conditioners, brooms, buckets, mops, pans, pans, pots"

The above quotation shows that in the textbook "My Friends of Indonesia" introduces household appliances as a cultural product in the form of living equipment and technology systems also appear on socalled objects. Cookware and food that is used in cooking food and at mealtimes. As well as equipment in cleaning the house, there are vacuum cleaners, air conditioners, brooms, buckets, mops. While cooking equipment such as pans, pans, knives and gas stoves. Next, the last cutlery such as plates, forks, and spoons.

\section{The complexity of Cultural Products in the Form of Livelihoods}

The complexity of cultural outcomes in the form of a livelihood system is also evident in the textbook "My Friends of Indonesia". Analysis of the existence of the complexity of cultural outcomes in the form of livelihood systems of life focused on objects used in certain fields of work.

The first data shows the complexity of cultural outcomes in the form of food-related to livelihoods in the form of trade. The tool used in trading is a cart. The quote is as follows.

\section{"Typical Food of West Java Cimol}

This is Kania's favorite food. This food is called Cimol. Cimol from West Java. Typical West Java Food Cimol This is Kania's favorite food. This food is called Cimol. Cimol from West Java”

The quote above shows that in the textbook "Friends of Indonesia" introduces the traditional meal of West Java, Cimol. Where Cimol is a snack for teenagers who are round and the basic ingredients are starch. Cimol is usually sold on the roadside at an affordable price. The tools used in selling Cimol are with a cart and a pan and so forth. The next quote is as follows:

\section{"Indonesian Batik Craftsmen}

Indonesia is a country that produces a lot of crafts. Someone who works to make crafts is called a craftsman"

The quotation above shows that in the textbook "Indonesian Sahabatku" introduces the livelihood system through the work of traders. In the textbook, the batik craftsman profession has long been developing in Indonesia. Indonesia is a country rich in Batiks such as in Yogyakarta, Bekalongan, and Solo. With the existence of batik craftsmen, one opened up jobs in ancient times. The process of making batik selects dyes originating from native plants in Indonesia that are made by yourself such as from the noni tree and soda from soda ash, while the salt is made from mud.

\section{The Complexity of Cultural Results in the Form of Religion}

The complexity of cultural outcomes in the form of religious systems is also found in the textbook "My Friends of Indonesia". Analysis of cultural outcomes in the form of religious systems will be focused on the existence of objects or facilities in the religious field.

Data obtained in the textbook "My Friends of Indonesia" in the form of objects and facilities in the religious field. The first data is in the form of Balinese offerings that are used to find blessings from the ancestors who have been trusted. The quote is as follows:

"Offering of Bali

In Indonesia, it is very closely related to traditional elements that still smell mystical.

Offerings are still often used in coastal areas that are considered sacred"

The quote above explains that the Balinese are still thick with their culture. Like offerings or offerings is a form of gratitude and offerings to seek blessings from ancestors who used to believe in religious thought. The offerings have a very sacred value to the views of the 
local community. As for the place where the ritual is performed, for example, a sacred place and has a high magical value. The following excerpts are as follows:

"On the coast of Pelabuhan Ratu, Sukabumi traditional ceremonies are carried out by giving offerings to the middle of the sea in the form of fish seeds, shrimp seeds, and turtle children"

The quote above explains that the Sukabumi area on the coast of the queen port still makes offerings to the sea. The tradition is carried out by fishermen who have gone downhill since ancient times and until now. These offerings are often known as traditional food anchor ceremonies to pay homage to a princess named Nyi Putri Mayangsagara for her concern for the welfare of fishermen. Formerly the offerings used were buffalo head/goat but now replaced by sprinkling fish seeds, shrimp seedlings (shrimp seedlings) and hatchlings (turtle children) into the middle of the Port ofatu Bay.

\section{The Complexity of Cultural Results in the Form of} Art

The complexity of cultural products in the form of art is also found in the textbook "My Friends of Indonesia". Data on the findings of the complexity of cultural products in the form of art in the form of tools and forms of art and some dance names. Cultural products in the form of the art form are stilt houses, where stilt houses are traditional houses in Indonesia. The results of culture in the form of dances such as candle dances, Jaipong dance and so on. While the results of other forms of cultural art that is folklore such as Sangguniang. The quote is as follows:

\section{“Rumah Panggung}

Let me introduce myself, I'm Kiki Adiyati. I live withmy family in Dago, Bandung, Indonesia. My house is a stilt house. This is a traditional Indonesian house"

The quotation above shows that in the past, houses on stilts were houses in Indonesia. But now, homes in Indonesia have many forms of modern homes. Stilt houses are basically made of wood. In the past, each room on stilts had different functions, for example, the Jambi stilt house, the first room named Jogan, which served as a resting place for family members and as a place to store water. The second room is the front porch that serves to receive male guests. The third room is the inner porch that functions as a boy's bed. The fourth room is a transverse amben that functions as a bridal chamber. The fifth room is the back porch as a sleeping room for unmarried girls. The sixth room is used to receive female guests. The seventh room is the fierce space that is used as well as the place to store water. eighth in the kitchen used for cooking. Jambi stilt houses are one of Indonesia's cultures. Then another quote is as follows:

"Saman dance

Saman dance is a traditional dance from Aceh"

In the above quote in the textbook "My Friends of Indonesia" introduces art or culture found in Indonesia, namely the Saman dance originating from Aceh. Saman dance is one of the media for the achievement of messages/da'wah that reflects education, religion, manners, heroism, cohesiveness, and togetherness. Before the saman dance began as a preamble or opening, a clever old man or traditional leader appeared to represent the local community (keketar) or useful advice to the players and the audience. The song and poetry of its disclosure together and continuously, the cast consists of men who are still young by wearing traditional clothing. The dance presentation can also be staged, competed between guest groups and group groups (two groups). Assessment is focused on the ability of each group to follow the movements, dance and song (poetry) presented by the opposing party.Next quote about art in Indonesia as follows:

"Jaipong is a typical Sundanese dance whose movements are very dynamic, spontaneous, full of improvisation, and easily accepted by people from all walks of life. These dance movements are based on the music of Ketuk Tilu and the Pencak Silat (Sundanese martial arts) movement"

The quote is contained in the textbook "Indonesian Sahabatku" which introduces cultural results in Indonesia one of which is a Jaipong dance originating from West Java. The Jaipong dance is an amalgamation of several traditional arts such as Wayang Golek, Pencak Silat and Tap Tilu. The accompanying music for the Jaipong dance performance uses musical instruments such as Degung, Gendang, Gong, and other musical instruments. Jaipong dance is very popular in Bandung, West Java. Even though in Indonesia a lot of modern entertainment is present, traditional art, namely the Jaipong dance, is still in demand and is an interesting entertainment for the people. Therefore, the Jaipong dance became one of the icons to promote regional wealth, especially Bandung. In Bandung, the Jaipong dance is increasingly becoming a fan or spectator of the dance performance. Next quote about art in Indonesia as follows:

"Lilin Dance is a traditional dance from West Sumatra. In this dance, dancers use candles placed on a small plate in his hand" 
In the quote above the cultural results contained in the textbook, "Indonesian Sahabatku" explains that the Lilin dance is a traditional dance originating from West Sumatra. The dance of the candle is played by the dancers by using a small plate with a candle burning on it as an attribute of dancing. The candle dance is played by a group of dancers with attractive movements and in rhythm with the music that accompanies it. Candle Dance is one of the famous dances in Indonesia and has become one of the icons of traditional dances in West Sumatra, especially the Minangkabau community. In addition, Lilin dance has a function that was original as a custom event, namely as a ceremony of gratitude to God for the results and achievements obtained by the community. But nowadays, the Lilin dance is not only displayed for traditional events, but rather as art and entertainment.

\section{"Panjat Pinang}

Rock climbing is a type of competitive game which is usually held at the Indonesian Independence Day celebrations"

In the quote above there are cultural results in the form of traditional games contained in the textbook "Indonesian Sahabatku". Panjat Pinang is one of the popular traditional competitions on Indonesia's Independence Day celebrations. The method of the game is a tall areca palm tree and the trunk is covered with lubricant, and prepared by the competition committee. In the tree section, various attractive prizes are prepared. The participants competed to get the prizes by climbing the areca palm tree trunks.

\section{CONCLUSION}

Based on the results of research on the complexity of cultural results in the textbook "Indonesian friends". consists of the complexity of cultural outcomes such as livelihood (MH) $37.5 \%$, equipment and life technology (PH) $6.25 \%$, arts (K) $31.25 \%$, knowledge systems (SP) $6.25 \%$, religion ( $\mathrm{R}$ ) $6.25 \%$ and language (B) $12.5 \%$. Thus, the most prominent results in the textbook "My Friends of Indonesia are livelihoods and arts. So, from these results that the role of culture in BIPA learning is very important. One reason foreign students learn Indonesian is because of the diversity of cultures found in Indonesia.

Through the complexity of cultural outcomes as teaching,the material is already supporting and in accordance with student needs. The complexity of this study also illustrates that physical culture is a form of human work. These cultural products include universal culture as stated above. The results of these cultures indicate the existence of various kinds of physical objects or that appears to be man-made.

\section{REFERENCES}

[1] S. Rachman, Ichsan Fauzi, Andayani, "Cultural Issues in Indonesian Language Learning for Foreign Speakers," Int. J. Educ. Res. Rev., no. 1993, pp. 454-460, 2019.

[2] U. Qomariyah, "Indonesian Language Learning Strategy for Foreign Speakers Containing Local Cultural," Int. Conf. Educ. Proceeding, vol. 1, no. July, pp. 399-406, 2016.

[3] M. A. R. Nur, "Bipa Sebagai Strategi Kebudayaan Dan Implementasinya Dalam Metode Pembelajaran," Pros. SEMNAS KBSP V BIPA, vol. 53, no. 9, pp. 1689-1699, 2019.

[4] J. Sharif Matthews and F. López, "Speaking their language: The role of cultural content integration and heritage language for academic achievement among Latino children," Contemp. Educ. Psychol., vol. 57, no. xxxx, pp. 72-86, 2019.

[5] N. Mathew Joseph, P. Ramaswamy, and J. Wang, "Cultural factors associated with physical activity among U.S. adults: An integrative review," Appl. Nurs. Res., vol. 42, no. May, pp. 98-110, 2018.

[6] K. Saddhono, "Integrating Culture In Indonesian Language Learning For Foreign Speakers At Indonesian Universities," J. Lang. Lit., 2015.

[7] C. Kramsch, Context and Culture in Language Teaching. Oxford, UK: Oxford University Press, 1998.

[8] E. Subali, "Konsep Bilingualisme Dan Pembelajaran Bahasa Indonesia Bagi Penutur Asing," J. Sos. Hum., vol. 8, no. 1, p. 106, 2015.

[9] I. Suyitno, Y. Pratiwi, Roekhan, and Martutik, "How Prior Knowledge, Prospect, and Learning Behaviour Determine Learning Outcomes of BIPA Students?," Cakrawala Pendidik., vol. 38, no. 3, pp. 499-510, 2019.

[10] R. K. Ningrum et al., "BIPA (Bahasa Indonesia Penutur Asing) Sebagai Upaya Internasionalisasi Universitas Di Indonesia," 1st Educ. Lang. Int. Conf. Proc., pp. 726-732, 2015.

[11] S. P. Ritiauw, "The Development Of Design Model Of Conflict Resolution Education Based On Cultural Values Of Pela," J. Cakrawala Pendidik., vol. 36, no. 1, pp. 35-40, 2017.

[12] A. Liddicoat, A. J., \& Scarino, Intercultural language teaching and learning. Chichester: John Wiley \& Sons, 2013.

[13] R. Curtis, A. Robertson, and I. Mahony, "Intercultural language learning: the Indonesian for Teachers Initiative (InTI) experience," Lang. Intercult. Commun., vol. 19, no. 4, pp. 357-370, 2019.

[14] C. Series, "Gamelan as a Learning Media Speaking Skills to Indonesian Language Students For Foreign Speakers ( BIPA ) Gamelan as a Learning Media Speaking Skills to Indonesian Language Students For Foreign Speakers ( BIPA )," 2019.

[15] E. Wenger, Communities of practice: Learning, meaning, and identity. New York, NY: Cambridge University Press, 1998.

[16] E. Lave, J., \& Wenger, Situated learning: Legitimate peripheral participation. Cambridge: University Press, 1991. 